\title{
Juliusz Giżyński
}

Sopocka Szkoła Wyższa

e-mail: jgizynski@ssw.sopot.pl

\section{WYDAJNOŚĆ FISKALNA PODATKU BANKOWEGO W POLSCE W POCZĄTKOWYM OKRESIE JEGO FUNKCJONOWANIA}

\section{FISCAL EFFICIENCY OF BANK LEVY IN POLAND AT THE EARLY STAGE OF ITS FUNCTIONING}

DOI: $10.15611 /$ nof.2017.1.02

JEL Classification: E6, H2, H3, H6

Streszczenie: Głównym celem autora artykułu jest zbadanie wydajności fiskalnej podatku bankowego w Polsce w początkowym okresie jego funkcjonowania. Podatek ten przyjęto ustawą o podatku od niektórych instytucji finansowych na początku 2016 roku. W krajach Unii Europejskiej jego koncepcję zaczęto stosować szerzej po międzynarodowym kryzysie subprime, głównie jako reakcję na hazard moralny banków i jego ogromne skutki dla podatników krajów Unii. Polski podatek bankowy ma z kolei charakter wyłącznie fiskalny. Do przygotowania tego artykułu posłużyła metoda badawcza, jaką jest studium literatury oraz analiza szacunkowych danych z Ministerstwa Finansów. Przeprowadzone badania umożliwiły sformułowanie wniosku, że dochody z podatku bankowego w Polsce w okresie marzec wrzesień 2016 r. kształtowały się znacznie poniżej prognozy, a główną tego przyczyną są wady jego konstrukcji. Aby poprawić wydajność fiskalną tej daniny, należałoby m.in. uszczelnić przepisy, ograniczyć praktykę przenoszenia udzielania kredytów za granicę oraz zmienić regulacje dotyczące wprowadzania programów naprawczych.

Słowa kluczowe: podatek bankowy, wydajność fiskalna podatku.

Summary: The main aim of the article is to examine fiscal efficiency of bank levy in Poland in the initial period of its functioning. This levy was implemented by the Law of the Tax for certain Financial Institutions at the beginning of 2016. In the European Union countries its idea was applied after the international subprime crisis, mainly as a reaction to banks' moral hazard and its huge results for taxpayers from the above mentioned countries. Polish bank levy has in turn only fiscal character. To prepare this article some scientific methods were used, such as the study of literature and the analysis of estimated data prepared by the Ministry of Finance. The conducted research allowed to draw a conclusion that bank levy incomes in Poland between March and September 2016 were substantially below the forecast. The main reason for this is that the construction of this tax has some disadvantages. In order to improve its fiscal efficiency, there should be necessary, among others things, to tighten up legislation, limit the practice of transferring granting credits abroad and change regulations concerning the implementation of rescue programmes.

Keywords: bank levy, fiscal efficiency of tax. 


\section{Wstęp}

Od 2009 roku daninę bankową w formie podatku bądź opłaty wprowadzono w kilkunastu krajach Unii Europejskiej ${ }^{1}$. Działanie to było reakcją na hazard moralny banków oraz jego ogromne skutki dla podatników państw członkowskich. Najważniejszym argumentem za dodatkowym obciążeniem był fakt, że prywatne banki, $\mathrm{z}$ jednej strony, doprowadziły do finansowej katastrofy, z drugiej zaś zostały uratowane za pomocą publicznych środków o niewyobrażalnej skali i teraz powinny one ponieść z tego tytułu finansową odpowiedzialność (financial crisis responsibility fee). Warto podkreślić, iż rządy krajów należących do UE wydały na ratowanie banków w formie kapitałów, pożyczek oraz gwarancji 10,3\% PKB Unii z 2008 roku. W niektórych przypadkach koszty te doprowadziły budżety państw do granic bankructwa. W przypadku Irlandii, której wskaźnik zadłużenia publicznego przed kryzysem finansowym był najniższy w strefie euro i wynosił zaledwie $25 \%$, wzrósł do 123\% w 2014 r. [Pawłowicz 2015]. Innym argumentem wprowadzenia podatku (opłaty) bankowego, szczególnie podnoszonym przez instytucje UE oraz środki masowego przekazu, była kwestia bardzo wysokich wynagrodzeń (w formie bonusów, premii, odpraw) kadry zarządzającej w zagrożonych bankructwem bankach. Ponadto w międzynarodowych raportach pokryzysowych zalecano m.in. stworzenie systemu finansowania procesów naprawczych oraz uporządkowanej likwidacji instytucji finansowych (recovery and resolution regime plan) [Dec, Masiukiewicz 2013, s. 22-23].

W Polsce zdecydowano się na przyjęcie dodatkowej daniny bankowej w formie podatku. Przyjęto go przez ustawę o podatku od niektórych instytucji finansowych na początku 2016 r. [Ustawa z dnia 15 stycznia 2016 r.]. W przeciwieństwie do regulacji uchwalonych w większości krajów UE, polski podatek bankowy ma charakter wyłącznie fiskalny. Projektodawcy uzasadniają jego wprowadzenie koniecznością zwiększenia udziału sektora finansowego w ponoszeniu obciążeń podatkowych oraz wysoką jego zyskownością [NBP 2016, s. 118]. Warto przypomnieć, iż jest to czwarta próba pozyskania daniny publicznej z sektora finansowego, głównie bankowego, w tym druga udana. W 2013 roku przyjęto bowiem rozwiązanie, w ramach ustawy o Bankowym Funduszu Gwarancyjnym [Ustawa z dnia 14 grudnia 1994 r., art. 7], nakładające opłatę ostrożnościową na banki. Rozwiązanie to wpisuje się w ideę przenoszenia ryzyka wsparcia tych instytucji, w przypadku kryzysu, z sektora publicznego na podmioty rynku finansowego. $Z$ kolei dwie nieudane inicjatywy ustawodawcze miały miejsce w latach 2010 i 2011, jednakże różniły się one znacznie od aktualnie przyjętych rozwiązań podatku bankowego [Gajewski 2016, s. 2-4]. Należy

${ }^{1}$ W 2009 roku daninę tę wprowadziła Szwecja, w 2010 r. Węgry i Włochy, w 2011 r. Austria, Cypr, Dania, Francja, Łotwa, Niemcy, Portugalia, Rumunia, Słowenia i Wielka Brytania, w 2012 r. Belgia, Holandia i Słowacja, w 2013 r. zaś Finlandia. Już od dłuższego czasu funkcjonowała ona w Grecji (od 1975 r.) oraz w Hiszpanii (od 2001 r.). Warto podkreślić, iż konstrukcje danin bankowych w powyższych krajach mają zróżnicowany charakter [Gajewski 2016, s. 14-15]. 
jednocześnie podkreślić, iż wprowadzenie tego podatku w polskich warunkach wzbudzało oraz wciąż wzbudza wiele kontrowersji.

Głównym celem artykułu jest zbadanie wydajności fiskalnej podatku bankowego w Polsce w początkowej fazie jego funkcjonowania. Zaprezentowano w nim przede wszystkim konstrukcję prawną tego podatku i wynikające z niej wady, a także dokonano analizy i oceny kształtowania się wpływów z jego tytułu do budżetu państwa polskiego w okresie marzec - wrzesień 2016 roku. W przygotowaniu artykułu wykorzystano metodę badawczą studium literatury oraz analizę szacunkowych danych przygotowanych przez Departament Budżetu Państwa w Ministerstwie Finansów.

\section{Wybrane aspekty $z$ teorii podatku bankowego}

Podatek bankowy jest konstrukcją zaliczaną do grupy tzw. podatków majątkowych. Zaczęto stosować go szerzej dopiero po międzynarodowym kryzysie subprime ${ }^{2}$. Ogólnie przyjęta definicja stanowi, że podatek ten jest obciążeniem publicznoprawnym, adresowanym do określonej grupy podmiotów finansowych, tj. banków i niektórych parabanków. W szerokim ujęciu do podatku bankowego zalicza się zarówno podatki dotyczące operacji bądź niektórych przychodów, jak i opłaty bankowe (bank levy). W związku z tym podatek ten może przyjąć formę zarówno podatku pośredniego, jak i bezpośredniego.

Z perspektywy teorii podatkowi bankowemu (opłacie) przypisuje się wiele funkcji. Zależą one od charakteru polityki fiskalnej, który przyjmują rządy w określonych państwach. Można wyróżnić następujące cele poboru tego podatku:

- fiskalne - dostarcza dochodów do budżetu państwa,

- zmniejszające ryzyko - np. podatek kryzysowy,

- wyrównywanie obciążeń podatkowych w danym sektorze gospodarki - np. traktowany jako substytut podatku VAT w bankowości,

- prorozwojowe - stosowanie różnych ulg i zwolnień,

- sanacyjne - gromadzenie funduszy naprawczych czy dotyczących wykupu złych długów,

- stabilizacji systemu finansowego - np. zasilanie funduszy stabilizacyjnych, akumulacja środków w budżecie państwa.

Mogą wystąpić sytuacje, kiedy ustawodawca zawrze kilka z wymienionych celów w jednym modelu podatku [Dec, Masiukiewicz 2013, s. 17-18].

Sformułowano wiele przesłanek za wprowadzeniem podatku bankowego i przeciw jego wprowadzeniu. Wśród najważniejszych argumentów „za” wymienia się:

- większą stabilność finansową,

- mniej spekulacji finansowych,

${ }^{2}$ Słowem subprime określa się kredyty o podwyższonym ryzyku udzielone osobom o niskiej zdolności kredytowej. Nie ma ono odpowiednika w języku polskim. 
- niższe koszty ratowania banków w przyszłości w związku z ograniczeniem wykorzystania funduszy publicznych,

- możliwość przeznaczenia zgromadzonych środków z podatku na restrukturyzację banków będących w ciężkiej sytuacji finansowej.

Z kolei do argumentów ,przeciw” zaliczymy m.in.:

- wzrost cen produktów oraz usług bankowych,

- brak równego traktowania wszystkich instytucji finansowych,

- zróżnicowane stawki i podstawy opodatkowania w poszczególnych krajach,

- niższą zdolność banków do gromadzenia kapitałów,

- zmniejszenie efektywności banków, a co za tym idzie - osłabienie ich pozycji konkurencyjnej na globalnym rynku finansowym,

- utrudnione oddzielenie transakcji spekulacyjnych od zabezpieczających,

- przeniesienie działalności lokalnych banków do innych państw, gdzie podatek bankowy nie występuje (tzw. arbitraż regulacyjny),

- wykorzystanie dochodów z podatku na inne cele niż ochrona stabilności finansowej [Dec, Masiukiewicz 2013, s. 21-22].

Podstawa naliczania podatku bankowego może być zróżnicowana. Mogą ją stanowić:

- aktywa,

- aktywa ważone ryzykiem,

- aktywa i zobowiązania pozabilansowe ważone ryzykiem,

- pasywa,

- zobowiązania,

- pasywa - z wyłączeniem kapitału własnego oraz gwarantowanych depozytów,

- suma bilansowa oraz zobowiązania pozabilansowe, których udzielono,

- całkowity wymóg kapitałowy,

- zysk - ewentualnie powiększony wynagrodzeniami i/lub premiami,

- transakcje - obrót instrumentami finansowymi,

- czynności bankowe (finansowe),

- innowacyjne instrumenty finansowe.

Opodatkowanie sektora bankowego należy oceniać nie tylko pod kątem wysokości jego zysku. Niezwykle istotne jest również to, aby jego poziom miał akceptację społeczeństwa. Konieczne jest też oszacowanie ryzyka spadku atrakcyjności inwestycyjnej banków dla prywatnego kapitału oraz zaangażowanie środków publicznych w celu zapewnienia bezpieczeństwa całego systemu finansowego. Jednakże powyższe stwierdzenia nie przeczą idei opodatkowania banków na rzecz dobra wspólnego, a szczególnie na rzecz wzrostu stabilności systemu finansowego. Istota wyboru leży bowiem między celem fiskalnym opodatkowania powyższych instytucji, z natury krótkookresowym, a wzrostem stabilności systemu finansowego. Wzrost tej stabilności oznacza przede wszystkim zmniejszenie ryzyka niestabilności finansów publicznych w dłuższym okresie. Dlatego istotne jest to, aby przyjęta podstawa opodatkowania w podatku bankowym prowadziła do wyższego obciążenia 
tych instytucji, które podejmują bardziej ryzykowną działalność oraz tworzą zagrożenie dla stabilności systemu finansowego. Mniejszy podatek zaś płaciłyby banki nietworzące takiego zagrożenia [Pawłowicz 2015].

Warto przypomnieć, iż rynek finansowy we współczesnej gospodarce rynkowej cechuje się pewnymi niedoskonałościami. Należą do nich m.in. negatywne efekty zewnętrzne. Ich pojęcie wprowadził A.C. Pigou na początku trzeciej dekady XX wieku. Ekonomista ten zwrócił uwagę na występowanie dwu rodzajów efektów zewnętrznych: pieniężnych i niepieniężnych. Pierwsze z nich powstają poprzez mechanizm rynkowy, który transmituje zmiany popytu i podaży czynników produkcji. Drugie zaś dotyczą części kosztów produkcji przenoszonych na podmioty rynkowe, które nie biorą bezpośredniego udziału w procesie wymiany. Wówczas cena produktu bądź usługi przestaje być efektywnym parametrem równowagi rynkowej [Kil, Ślusarczyk 2014, s. 125].

Podatki bankowe wprowadzone w ostatnich latach przez państwa należące do Unii Europejskiej mają swoje źródło właśnie w argumentacji Pigou. Podstawą opodatkowania tych danin są zazwyczaj pożyczki zaciągane przez banki. Podatek ten bowiem powinien obciążać finansowanie działalności bankowej, która zwiększa ryzyko wystąpienia kryzysu. Zgodnie z regułą Pigou podatki bankowe mogą również dotyczyć większego obciążenia pożyczek krótkoterminowych (w porównaniu z długoterminowymi), a ich skala może przyjmować formę progresywną [Kil, Ślusarczyk 2014, s. 127].

Przyjęcie podatku bankowego wymaga głębszej refleksji. Brak oceny potencjalnych skutków ustanowienia tej daniny może spowodować m.in. długoterminowe negatywne konsekwencje dla rozwoju zarówno sektora bankowego, jak i całej gospodarki [Dec, Masiukiewicz 2013, s. 22]. Niezwykle istotne jest to, aby tego typu podatek nie generował ryzyka dla stabilności finansowej oraz dynamiki akcji kredytowej banków, co w ostateczności może zaszkodzić wzrostowi realnej gospodarki. W efekcie mogłoby dojść do pogorszenia warunków kredytów lub innych usług świadczonych przez banki oraz wytworzenia dla tych instytucji sytuacji niepewności [EBC 2016, s. 3].

\section{Konstrukcja prawna podatku bankowego w Polsce i wynikające $z$ niej kontrowersje}

W 2016 roku przyjęto wiele nowych rozwiązań prawnych w polskim systemie podatkowym. Jedną ze zmian o charakterze rewolucyjnym jest ustawa o tzw. podatku bankowym [Witczak 2015, s. 105-106]. Opublikowano ją w styczniowym dzienniku ustaw, a jej pełna nazwa to Ustawa z dnia 15 stycznia 2016 r. o podatku od niektórych instytucji finansowych (zwana dalej ustawą). Jej przepisy zaczęły obowiązywać z dniem 1 lutego 2016 r. [Ustawa z dnia 15 stycznia 2016 r., art. 15]. Wprowadzenie podatku bankowego jest realizacją obietnicy wyborczej przedkładanej w kampanii do parlamentu w Polsce jesienią 2015 r. [Witczak 2016, s. 160]. 
W ustawie zapisano, że podatek bankowy stanowi dochód budżetu państwa, przedmiotem opodatkowania zaś są aktywa podmiotów będących jego podatnikami [Ustawa z dnia 15 stycznia 2016 r., art. 2 i 3]. Polski podatek bankowy nie ma związku z konkretnymi ryzykami odnoszącymi się do systemu finansowego. Nie dotyczy on również pomocy publicznej uprzednio udzielonej sektorowi finansowemu. Ma on charakter, jak już wspominano, wyłącznie fiskalny. Może więc dojść do sytuacji, że jego podatnicy, w związku z chęcią uniknięcia płacenia tej daniny, będą podejmować działania (transakcje), które nie mają wpływu na poziom ich sumy bilansowej.

Ponadto aktywa będące przedmiotem opodatkowania wykorzystuje się również przy ustalaniu wpłat na koszty nadzoru bankowego. Co więcej, część aktywów instytucji finansowych objęta jest podatkiem od nieruchomości. W związku z tym niektóre zasoby tych instytucji zostaną opodatkowane dwukrotnie całkowicie odrębnymi podatkami majątkowymi [Gajewski 2016, s. 5-6].

Kolejna kwestia dotyczy szerokiego zakresu podmiotowego. Ustawa obejmuje nie tylko banki krajowe, ale również inne instytucje finansowe [Witczak 2016, s. 160]. Zgodnie $\mathrm{z}$ art. 4 podatnikami podatku bankowego są również:

- oddziały banków zagranicznych i instytucji kredytowych,

- spółdzielcze kasy oszczędnościowo-kredytowe,

- krajowe zakłady ubezpieczeń oraz reasekuracji,

- oddziały zagranicznych zakładów ubezpieczeń i reasekuracji,

- główne oddziały zagranicznych zakładów ubezpieczeń oraz reasekuracji,

- instytucje pożyczkowe [Ustawa z dnia 15 stycznia 2016 r., art. 4].

Ostatnia wyszczególniona grupa, czyli instytucje pożyczkowe, dotyczy dość szerokiego ujęcia podatnika [Ustawa z dnia 12 maja 2011 r., art. 3 i 5]. W związku z tym po przyjęciu ustawy o podatku bankowym pojawiły się wątpliwości, czy udzielanie pożyczek własnym pracownikom z Zakładowego Funduszu Świadczeń Socjalnych bądź ze środków obrotowych również będzie podlegało nowej daninie. Na początku marca 2016 r. Ministerstwo Finansów [Interpretacja... 2016, s. 3] wyjaśniło jednak, że przedsiębiorstwa udzielające takich pożyczek swoim pracownikom nie są podmiotem tego podatku [Witczak 2016, s. 160-161].

Następna uwaga ma związek z bankami krajowymi, które prowadzą swoją działalność na obszarze państw Unii Europejskiej. Warte rozważenia jest zwolnienie aktywów tych oddziałów z opodatkowania podatkiem bankowym. Dotyczy to szczególnie tych podmiotów, których aktywa byłyby obciążone podobnym podatkiem stosowanym przez kraj goszczący. Analogiczna sytuacja wystąpi w wypadku opodatkowania aktywów oddziałów instytucji kredytowych płacących już taki podatek w krajach macierzystych UE [Gajewski 2016, s. 6].

Podstawą opodatkowania w podatku bankowym, zgodnie z art. 5 ustawy, jest nadwyżka sumy wartości aktywów podatnika, która wynika z zestawienia jego obrotów i sald. Zestawienie to ustala się na ostatni dzień miesiąca w oparciu o zapisy na kontach księgi głównej, prowadzonych zgodnie z przepisami o rachunkowości [Ustawa z dnia 15 stycznia 2016 r., art. 5]. Zgodnie z interpretacją Ministra Finan- 
sów [Interpretacja... 2016, s. 2] przy ustalaniu wartości poszczególnych części aktywów należy również uwzględnić konta korygujące. Za przykład można podać środki trwałe, które pomniejsza się o wartość ich umorzenia [Witczak 2016, s. 161].

Należy także zwrócić uwagę na moment ustalenia podstawy opodatkowania, tj. ostatni dzień miesiąca. Kwota tej podstawy bowiem nie jest potwierdzana przez biegłego rewidenta. Warto byłoby więc skorzystać z doświadczeń przy wyliczaniu podstawy rezerwy obowiązkowej, którą utrzymują instytucje finansowe w Narodowym Banku Polskim (NBP). Nalicza się ją w oparciu o średnią arytmetyczną ze stanów środków pieniężnych na koniec każdego dnia danego miesiąca. Umożliwia to zminimalizowanie zjawiska manipulowania wysokością środków, które mają stanowić podstawę wyliczenia tej rezerwy [Gajewski 2016, s. 7]. Nie można zaś tego dokonać przy określaniu podstawy opodatkowania w podatku bankowym.

$\mathrm{W}$ art. 5 ustawy określono również progi kwotowe, które zwalniają z podatku bankowego. Kształtują się one w następujący sposób:

- 4 mld zł - dla banków krajowych, oddziałów banków zagranicznych i instytucji kredytowych oraz spółdzielczych kas oszczędnościowo-kredytowych,

- 2 mld zł - dla krajowych zakładów ubezpieczeń oraz reasekuracji, oddziałów zagranicznych zakładów ubezpieczeń i reasekuracji, a także głównych oddziałów zagranicznych zakładów ubezpieczeń oraz reasekuracji,

- $200 \mathrm{mln} \mathrm{zl}$ - dla instytucji pożyczkowych [Ustawa z dnia 15 stycznia 2016 r., art. 5, pkt 1-3].

Należy zauważyć, że dwa pierwsze progi zwalniające wydają się bardzo wysokie jak na warunki panujące na polskim rynku finansowym [Gajewski 2016, s. 7].

W bankach krajowych, oddziałach banków zagranicznych i instytucji kredytowych oraz spółdzielczych kasach oszczędnościowo-kredytowych podstawę opodatkowania obniża się o wartość funduszy własnych ustaloną na ostatni dzień miesiąca. Aktywa powyższych instytucji pomniejsza się również o wartość skarbowych papierów wartościowych. Ponadto banki krajowe, oddziały banków zagranicznych i instytucji kredytowych zmniejszają swoją podstawę o wartość aktywów nabytych od Narodowego Banku Polskiego, będących zabezpieczeniem kredytu refinansowego, którego udzielił ten bank. Z kolei banki spółdzielcze obniżają ją o wartość środków zgromadzonych na wszystkich rachunkach zrzeszonych banków spółdzielczych prowadzonych przez podatnika [Ustawa z dnia 15 stycznia 2016 r., art. 5, pkt 1-6, 8-9].

$Z$ powyższej analizy wynika, iż zapisy ustawy o podatku bankowym nie uwzględniają obniżenia podstawy opodatkowania o fundusze własne ubezpieczycieli, co wydaje się niewłaściwe z perspektywy równego traktowania podmiotów. Z kolei możliwość odliczenia od podstawy wyłącznie krajowych skarbowych papierów wartościowych stoi w sprzeczności z zasadą zarówno swobody przepływu kapitału, jak i uczciwej konkurencji. Rozsądne wydaje się więc rozszerzenie tego zapisu o dłużne papiery Europejskiego Banku Centralnego (EBC), rządów banków centralnych krajów należących do Unii Europejskiej oraz Organizacji Współpracy Gospodarczej i Rozwoju (Organisation for Economic Co-operation and Development, 
OECD). Zasadne wydaje się także zwolnienie obligacji emitowanych przez Bank Gospodarstwa Krajowego (BGK), którym przypisuje się zerowy poziom ryzyka. Ponadto warte rozważenia jest obniżenie podstawy opodatkowania o wartość hipotecznych listów zastawnych ${ }^{3}$, a przynajmniej tych o publicznym charakterze ${ }^{4}$ [Gajewski 2016, s. 8-9].

Miesięczną stawkę podatku bankowego w Polsce ustalono na poziomie 0,0366\% podstawy opodatkowania [Ustawa z dnia 15 stycznia 2016 r., art. 7]. Ponadto pobór tego podatku odbywa się bez wezwania. Jego podatnicy są zobowiązani do składania deklaracji podatkowych, obliczania podatku i wpłacania go do właściwego ${ }^{5}$ urzędu skarbowego za miesięczne okresy rozliczeniowe. Przekazanie daniny musi nastąpić do 25 dnia miesiąca następującego po miesiącu, którego podatek dotyczy [Ustawa z dnia 15 stycznia 2016 r., art. 8]. Pierwszym okresem rozliczeniowym został luty 2016 r. [Ustawa z dnia 15 stycznia 2016 r., art. 13].

Podatek od niektórych instytucji finansowych to jedyna konstrukcja w polskim systemie podatkowym, którą reguluje się za każdy miesiąc. Zastrzeżenie budzi fakt, że suma aktywów w niezatwierdzonym sprawozdaniu finansowym może się różnić od wartości wykazanej w wersji zaudytowanej. Istnieje więc niebezpieczeństwo, że instytucje finansowe obciążone tym podatkiem będą zaniżać jego podstawę. Dlatego właściwszym rozwiązaniem byłoby określanie podstawy tego podatku z zastosowaniem zatwierdzonego rocznego sprawozdania finansowego. A zatem pobór tego podatku mógłby się odbywać w taki sposób, że najpierw pobierano by zaliczkę na podatek, a jej wysokość wynikałaby z ostatniego rocznego sprawozdania finansowego. Natomiast obowiązek złożenia deklaracji podatkowych następowałby po zatwierdzeniu sprawozdania finansowego za rok obrotowy [Gajewski 2016, s. 9].

Jeszcze przed uchwaleniem nowego podatku wskazywano, że przyjęcie aktywów za podstawę opodatkowania banków powinno mieć miejsce w przypadku przerostu ich sektora. Pojawiały się sugestie, aby unikać wprowadzenia tego rodzaju podstawy, a jeśli już ją się wybierze, to należy wyłączyć z niej kredyty. Miałoby to na celu zapobieżenie ograniczeniu dostępności kredytów zarówno dla gospodarki, jak i dla ludności [Pawłowicz 2015].

W ustawie o podatku od niektórych instytucji finansowych przewidziano również pewne ulgi i zwolnienia [Ustawa z dnia 15 stycznia 2016 r., art. 10-11]. Z po-

${ }^{3}$ Hipoteczny list zastawny jest wieloletnim, pożyczkowym papierem wartościowym, emitowanym przez bank hipoteczny w celu refinansowania udzielonych kredytów długoterminowych, których spłata jest zabezpieczona zastawem na nieruchomości dłużnika wpisanym do księgi wieczystej [Bień, Bień 2010, s. 73].

${ }^{4}$ Publiczny list zastawny to emitowany przez bank hipoteczny wieloletni, pożyczkowy papier wartościowy. Za jego pomocą bank ten refinansuje inne, niż hipoteczne, udzielone kredyty, gwarantowane przez instytucje o bardzo wysokim ratingu finansowym, np. banki centralne państw należących do UE [Bień, Bień 2010, s. 73].

${ }^{5}$ Właściwym organem podatkowym jest naczelnik urzędu skarbowego przypisany do miejsca siedziby podatnika. Jeśli nie jest możliwe jego ustalenie, to właściwym organem zostaje Naczelnik Drugiego Urzędu Skarbowego w Warszawie-Śródmieściu [Ustawa z dnia 15 stycznia 2016 r., art. 9]. 
datku zwolniono przede wszystkim banki państwowe. Obecnie ${ }^{6}$ jedynym bankiem w Polsce o takim charakterze jest Bank Gospodarstwa Krajowego. Pewne wątpliwości budzi jednak teoretyczne rozważanie, czy zwolnienie to nie byłoby zasadne wyłącznie w przypadku BGK, a nie wszelkich banków państwowych, które teoretycznie można założyć. Należy przypomnieć, iż taki bank może zostać stworzony w oparciu o rządowe rozporządzenie bądź na wniosek Ministra Skarbu Państwa podlegający zaopiniowaniu przez Komisję Nadzoru Finansowego. Oprócz banków państwowych $\mathrm{z}$ podatku bankowego zwolniono podmioty będące w stanie likwidacji, zawieszenia lub upadłości oraz objęte programem naprawczym [Gajewski 2016, s. 10-11].

W przepisach końcowych analizowanej ustawy zapisano, że nałożenie nowej daniny na niektóre instytucje finansowe nie może być dla nich podstawą do zmiany warunków świadczenia usług finansowych oraz ubezpieczeniowych. Chodzi o te umowy, które zawarto przed dniem wejścia ustawy w życie [Ustawa z dnia 15 stycznia 2016 r., art. 14]. Powyższy zapis ma zapobiegać zjawisku przerzucalności podatku [Gomułowicz, Małecki 2013, s. 41-44]. Należy jednak przypomnieć, iż ustawodawca podatkowy ma małe możliwości ograniczenia tego zjawiska, racjonalnie postępujący podmiot bowiem, zgodnie z zasadą maksymalizacji, będzie się starał zminimalizować obciążenia podatkowe, które są kosztem prowadzonej przez niego działalności. Dlatego można się spodziewać, że podatnicy, w tym wypadku podatnicy podatku bankowego, podejmą starania, aby wykorzystywać wszelkie legalne możliwości unikania opodatkowania. Wszystkie podatki są bowiem przerzucalne [Gwiazdowski 2007, s. 230, 240-241]. Z kolei źródłem przychodów dla instytucji komercyjnych są ich klienci. To oni płacą za wszystko. Nie ma innego rozwiązania [Podatek warto... 2016, s. B-12].

Dokonana analiza konstrukcji prawnej podatku bankowego skłania do wniosku, że konstrukcja ta charakteryzuje się wieloma wadami. W związku z tym można ją łatwo obejść, co spowoduje zmniejszenie skuteczności poboru tego podatku [Gajewski 2016, s. 22].

Jeszcze przed przyjęciem analizowanej ustawy eksperci Europejskiego Banku Centralnego sygnalizowali, że struktura proponowanego podatku od niektórych instytucji finansowych może zachęcić instytucje finansowe do zmiany profilu ryzyka. Mogłoby do tego dojść w wyniku restrukturyzacji portfeli tych instytucji ukierunkowanej na bardziej ryzykowne produkty, wykorzystanie operacji pozabilansowych czy transferowanie aktywów za granicę [EBC 2016, s. 3].

\section{Analiza wydajności fiskalnej podatku bankowego w Polsce - próba oceny}

Ocenę, czy podatek od niektórych instytucji finansowych jest efektywnym źródłem zasilania budżetu państwa, warto rozpocząć od określenia pojęcia wydajności fiskalnej podatku. Nazywamy nią możliwość uzyskania maksymalnych dochodów bez

${ }^{6}$ Stan na dzień 30.09.2016. 
uszczerbku dla danego źródła dochodów podatkowych. Wydajność fiskalną podatku należy oceniać w oparciu o zdolność systemu podatkowego do generowania pokrycia dla wydatków publicznych, czyli zadań, które mają zostać sfinansowane przez państwo [Kosek-Wojnar 2012, s. 193]. Wydajność tej daniny zależy od takich czynników, jak: miejsce nałożenia, okres funkcjonowania, koszty poboru, okres rozliczeniowy (np. miesięczny, kwartalny czy roczny), poziom ściągalności, powszechność oraz elementy konstrukcji podatku [Kosek-Wojnar 2012, s. 195-196].

Jak już podkreślano, konstrukcja podatku bankowego w Polsce charakteryzuje się wieloma wadami, dlatego łatwo ją obejść. Powoduje to m.in. zmniejszenie wydajności (skuteczności) poboru tego podatku, co znajduje potwierdzenie w szacunkowych danych na temat wysokości dochodów budżetu państwa [MF 2016, s. 13-15].

W założeniach do ustawy budżetowej na 2016 r. zapisano, że prognozowane wpływy z podatku bankowego wyniosą 5,5 mld zł [Ustawa z dnia 25 lutego 2016 r.]. Wobec tego, że instytucje objęte tym podatkiem dokonały jego pierwszej wpłaty w marcu, do końca 2016 r. wniosą one 10 takich wpłat. Średnio więc podatek ten powinien zasilać miesięcznie konto budżetu państwa na kwotę $550 \mathrm{mln}$ zł, aby wypełnić prognozę. Tymczasem szacunkowe dane Ministerstwa Finansów [MF 2016, s. 13-15] wskazują, że w okresie marzec-wrzesień 2016 r. wpływało średnio ok. 200 mln zł mniej (czyli ok. 36,36\%), co pozwoliło w tym okresie łącznie zgromadzić z tytułu tego podatku kwotę 2,4 mld zł (czyli 44,41\% zaplanowanej kwoty na 2016 r.). Szczegółowe dane zawarto w tab. 1.

Tabela 1. Kształtowanie się dochodów z tytułu podatku bankowego w Polsce w okresie marzec-wrzesień 2016 r.

\begin{tabular}{|l|c|c|c|c|c|c|c|c|}
\hline \multicolumn{1}{|c|}{ Okres } & $\begin{array}{c}\text { Marzec } \\
2016\end{array}$ & $\begin{array}{c}\text { Kwiecień } \\
2016\end{array}$ & $\begin{array}{c}\text { Maj } \\
2016\end{array}$ & $\begin{array}{c}\text { Czerwiec } \\
2016\end{array}$ & $\begin{array}{c}\text { Lipiec } \\
2016\end{array}$ & $\begin{array}{c}\text { Sierpień } \\
2016\end{array}$ & $\begin{array}{c}\text { Wrzesień } \\
2016\end{array}$ & Suma \\
\hline Dochód (w tys. zł) & 364198 & 361151 & 338949 & 336401 & 349269 & 343111 & 349567 & 2442646 \\
\hline $\begin{array}{l}\text { Realizacja planu* } \\
\text { dochodu (w \%) }\end{array}$ & 6,62 & 6,57 & 6,16 & 6,12 & 6,35 & 6,24 & 6,36 & 44,41 \\
\hline
\end{tabular}

* W ustawie budżetowej na $2016 \mathrm{r}$. dochody z podatku bankowego zaplanowano na kwotę 5,5 mld zł.

Źródło: opracowanie własne na podstawie [MF 2016, s. 13-15].

Na podstawie danych z tab. 1 można stwierdzić, że miesięczne zmiany wielkości zapłaconego podatku bankowego nie są wielkie. Mniejsze wpływy od maja 2016 r. są spowodowane rozpoczęciem przez Bank Ochrony Środowiska (BOŚ Bank) procesu postępowania naprawczego, co jest podstawą do zwolnienia z tej daniny [UKNF 2016, s. 6; Gajewski 2016, s. 19]. Dzięki zapisom ustawy podatku bankowego nie zapłacił również inny bank komercyjny, tj. Bank BPH, którego część aktywów przejmuje Alior Bank [Franczyk 2016, s. 27].

Najbardziej obciążone podatkiem od niektórych instytucji finansowych są banki. Mimo to, jak zauważają eksperci Urzędu Komisji Nadzoru Finansowego w swoim ra- 
porcie, szereg wyłączeń i pomniejszeń zawartych w ustawie o podatku bankowym sprawia, że ich liczba nie przekracza 19 podmiotów. Z kolei udział aktywów banków, które regulują podatek bankowy, w aktywach sektora wynosi 75\% [UKNF 2016, s. 4-5].

Ponadto na wydajność omawianego podatku wpływa wzrost zainteresowania banków zakupem obligacji Skarbu Państwa, będących składnikiem obniżenia podstawy opodatkowania. Należy podkreślić, że wartość tych papierów w posiadaniu banków zobowiązanych do uiszczenia podatku od niektórych instytucji finansowych wzrosła od końca grudnia 2015 r. do końca maja 2016 r. o kwotę 54 mld zł, tj. o 33,07\%. W związku z tym łączna podstawa opodatkowania w bankach zmniejszyła się w tych pięciu miesiącach o $6,43 \%$, mimo że jej wzrost odnotowano w 4 podmiotach [UKNF 2016, s. 6-7]. Jeśli chodzi o obsługę zadłużenia państwa, to zwiększony popyt na obligacje skarbowe jest zjawiskiem pozytywnym. Jednakże utrzymanie tej tendencji będzie miało bardzo negatywny wpływ m.in. na wydajność fiskalną podatku bankowego.

Możliwą praktyką instytucji finansowych, która wpływa znacznie na obniżenie poziomu ich aktywów, a tym samym podstawy opodatkowania podatkiem bankowym, jest ,sztuczne przerzucanie portfela kredytowego między oddziałami tych instytucji”. Praktykę tę uznaje się za klasyczny przejaw agresywnego unikania opodatkowania. Dotyczy ona banków, które posiadają oddziały zagraniczne bądź powiązane spółki kapitałowe w innych krajach z mniejszymi obciążeniami podatkowymi. W takim razie mniejsze krajowe instytucje finansowe, niemające takich oddziałów, znajdą się w mniej korzystnej sytuacji. Może to skutkować szkodliwą konkurencją między instytucjami finansowymi.

Wpływ na ściągalność podatku bankowego ma również technika wyliczania podstawy opodatkowania, którą ustala się w oparciu o zestawienie obrotów i sald. Wynika to z braku zasad, które pozwoliłyby na precyzyjne jej określenie. Kwestia ta dotyczy zarówno instytucji finansowych, jak i ubezpieczeniowych. Ponadto miesięczne salda, jak już wspominano, nie są autoryzowane przez audytora. Zastrzeżenia budzi także technika wyliczenia podstawy opodatkowania od aktywów wyrażonych w obcych walutach [Gajewski 2016, s. 18-20].

Podatek od niektórych instytucji finansowych może również wpłynąć niekorzystnie na wysokość innych dochodów budżetowych przekazywanych przez sektor bankowy. $Z$ jednej strony, niższe zyski tego sektora powodują obniżenie potencjalnych przychodów z dywidend od banków, w których Skarb Państwa ma jakieś udziały. $Z$ drugiej zaś, mimo że instytucje bankowe nie będą mogły zaliczyć powyższej daniny do kosztów uzyskania przychodów, szacuje się, iż wpływy z podatku dochodowego od osób prawnych zmniejszą się, szczególnie w średnim i długim okresie, na skutek m.in. spadku aktywności krajowych banków oraz wzrostu kredytowania transgranicznego [NBP 2016, s. 119-120].

Można się zatem przychylić do stwierdzenia, że obowiązująca ${ }^{7}$ konstrukcja prawna podatku od niektórych instytucji finansowych jest podatna na agresywną

7 Stan na dzień 31.10.2016. 
oraz kreatywną optymalizację podatkową [Gajewski 2016, s. 23]. Dlatego należałoby wprowadzić kilka istotnych zmian w zakresie:

- uszczelnienia przepisów,

- ograniczenia praktyki przenoszenia udzielania kredytów za granicę,

- regulacji dotyczących wprowadzania programów naprawczych w instytucjach finansowych [Szymański 2016].

W następstwie tego, że dochody z podatku bankowego w Polsce w początkowym okresie jego funkcjonowania są dużo niższe, niż oczekiwano, w październiku 2016 r. pojawiła się informacja z Ministerstwa Finansów dotycząca możliwości zmian w konstrukcji prawnej tego podatku. Rozważa się m.in. zmianę w postaci uśrednienia stanu aktywów na wszystkie dni miesiąca. Brane jest także pod uwagę odniesienie się do stanu bilansowego na koniec roku. Uszczelnienie przepisów ma na celu zwiększenie wpływów do budżetu państwa [Krześniak-Sajewicz 2016, s. B-3].

Można jednak przypuszczać, że w dalszym ciągu będą podejmowane przez różne podmioty zabiegi mające na celu ograniczenie kosztów nowych podatków bankowych. Etyka zobowiązań w tej kwestii bywa bowiem niska, chociaż banki i inne instytucje kredytowe, będące podmiotami zaufania publicznego i podlegające szczególnym regulacjom i nadzorowi finansowemu, stosunkowo rzadko stosowały tego rodzaju praktyki [Owsiak (red.) 2015, s. 218].

Wydajność fiskalna poszczególnych podatków, jak i całego systemu podatkowego stanowi pochodną wielu czynników. Mają one charakter wewnętrzny oraz zewnętrzny, jednostkowy i kompleksowy. Warto przypomnieć, że istotne znaczenie ma nie tylko konstrukcja prawna poszczególnych kategorii obciążeń podatkowych, ale także ich charakter oraz format ekonomiczny. Niezwykle ważne są również budowa i spójność całego systemu podatkowego [Szołno-Koguc 2012, s. 393-394].

\section{Zakończenie}

Podatek bankowy, z definicji, jest obciążeniem publicznoprawnym adresowanym do określonej grupy podmiotów finansowych, m.in. banków. Idea jego wprowadzenia w krajach Unii Europejskiej pojawiła się po międzynarodowym kryzysie subprime. Głównym argumentem dodatkowego obciążenia był hazard moralny banków oraz jego ogromne skutki dla podatników krajów Unii. Ponadto środki gromadzone z tej daniny mają wzmocnić stabilność sektora bankowego. Z kolei polski podatek bankowy nie ma związku z konkretnymi ryzykami, które odnoszą się do systemu finansowego. Nie dotyczy on również pomocy publicznej uprzednio udzielonej sektorowi finansowemu. Przyjął on charakter wyłącznie fiskalny. Poza tym jego konstrukcja prawna charakteryzuje się wieloma wadami. $Z$ tego powodu łatwo ją obejść, co powoduje m.in. duże zmniejszenie wydajności fiskalnej tego podatku. Ma to swoje umocowanie w szacunkowych danych Ministerstwa Finansów. Według nich wpływy z podatku bankowego w okresie marzec-wrzesień 2016 r. były średnio miesięcznie niższe od zaplanowanej kwoty o ok. 36\%. W celu poprawy wydajności tej daniny 
należałoby przede wszystkim uszczelnić jej regulacje. Konieczne będą również ograniczenie praktyki przenoszenia udzielania kredytów za granicę oraz zmiana norm dotyczących wprowadzania programów naprawczych.

Podatki tworzące system podatkowy powinny być przede wszystkim wydajnym źródłem dochodów budżetowych. Władza, przyjmując nowe podatki, powinna sięgać po takie kategorie danin, które nie tylko przynoszą wpływy przewyższające koszty wymiaru i poboru podatku, ale przede wszystkim dostarczają niezbędną ilość środków pieniężnych na realizację określonych zadań i funkcji państwa [Szołno-Koguc 2012, s. 384].

Jednakże wszystko, co stworzył człowiek, w tym regulacje prawne, jest niedoskonałe i po jakimś czasie wymaga rewizji i poprawy. Tak jest również w odniesieniu do podatku od niektórych instytucji finansowych. Jeszcze przed jego wprowadzeniem pojawiały się sugestie, aby nie zniekształcać struktury rynku i podwyższyć podatek dochodowy od osób prawnych dla banków. Koncepcja ta się jednak nie zmaterializowała [Podatek warto... 2016, s. B-12].

\section{Literatura}

Bień A., Bień W., 2010, Stownik finansów, Difin, Warszawa.

Dec P., Masiukiewicz P., 2013, Podatek bankowy, Wydawnictwo C.H. Beck, Warszawa.

EBC, 2016, Opinia Europejskiego Banku Centralnego z dnia 12 stycznia 2016 r. o podatku od niektórych instytucji finansowych, CON/2016/1.

Franczyk J., 2016, Podatek straconej szansy, miesięcznik finansowy BANK, czerwiec, s. 26-28.

Gajewski D. J., 2016, Podatek bankowy w Polsce - zalety $i$ wady, Analizy i Studia CASP, 20 kwietnia, $\mathrm{nr} 1(1)$.

Gomułowicz A., Małecki J., 2013, Podatki i prawo podatkowe, LexisNexis, Warszawa.

Gwiazdowski R., 2007, Podatek progresywny i proporcjonalny. Doktrynalne przesłanki, praktyczne konsekwencje, WUW, Warszawa.

Interpretacja ogólna nr PK1.8201.1.2016 Ministra Finansów z dnia 3 marca 2016 r. w sprawie stosowania przepisów ustawy o podatku od niektórych instytucji finansowych przez organy podatkowe oraz organy kontroli skarbowej, 2016, DzU Ministra Finansów, Warszawa, 10 marca, poz. 22.

Kil K., Ślusarczyk R., 2014, Podatek bankowy w krajach unii europejskiej - ocena implementacji, Prace Naukowe Uniwersytetu Ekonomicznego we Wrocławiu, nr 348, Polityka ekonomiczna, Wrocław, s. 124-133.

Kosek-Wojnar M., 2012, Zasady podatkowe w teorii i praktyce, PWE, Warszawa.

Krześniak-Sajewicz M., 2016, Podatek bankowy do uszczelnienia, Rzeczpospolita z 19 października, nr 245, s. B-3.

MF, 2016, Sprawozdanie operatywne z wykonania budżetu państwa za styczeń - wrzesień 2016 roku, Warszawa, październik.

NBP, 2016, Raport o stabilności systemu finansowego, Departament Stabilności Finansowej, Warszawa, luty.

Owsiak S. (red.), 2015, Determinanty rozwoju Polski. Finanse publiczne, PTE, Warszawa.

Pawłowicz L., 2015, Stanowisko Instytutu Badań nad Gospodarka Rynkowa wobec opodatkowania banków w Polsce, IBnGR, Gdańsk, listopad. 
Podatek warto skorygować, 2016, Rozmowa M. Krześniak-Sajewicz ze Z. Jagiełłą - prezesem PKO BP, Rzeczpospolita z 18 maja, nr 115, s. B-12.

Szołno-Koguc J., 2012, Istota i czynniki determinujace wydajność fiskalna podatków i systemu podatkowego, Studia Ekonomiczne. Zeszyty Naukowe Wydziałowe Uniwersytetu Ekonomicznego w Katowicach, nr 108, Finanse w niestabilnym otoczeniu - dylematy i wyzwania. Finanse publiczne, Katowice, s. 384-395.

Szymański D., 2016, 5,5 mld zł z podatku bankowego? Nic z tego. Oto jak banki przechytrzyty min. Szałamache, http://businessinsider.com.pl/finanse/podatek-bankowy-nizsze-wplywy/jz3cjqx (dostęp 31.10.2016).

UKNF, 2016, Syntetyczna informacja na temat wptywu podatku od niektórych instytucji finansowych na sytuację banków komercyjnych, Departament Bankowości Komercyjnej i Specjalistycznej oraz Instytucji Płatniczych, Warszawa, lipiec.

Ustawa z dnia 14 grudnia 1994 r. o Bankowym Funduszu Gwarancyjnym, DzU 1995, nr 4, poz. 18 ze zm.

Ustawa z dnia 12 maja 2011 r. o kredycie konsumenckim, DzU 2011, nr 126, poz. 715 ze zm.

Ustawa z dnia 15 stycznia 2016 r. o podatku od niektórych instytucji finansowych, DzU 2016, poz. 68, 996.

Ustawa budżetowa na rok 2016 z 25 lutego 2016 r., poz. 278.

Witczak R., 2015, Dodatek kwartalny: Zmiany w świecie podatków na rok 2016, Finanse i prawo finansowe, vol. II, nr 4, grudzień, s. 105-106.

Witczak R., 2016, Dodatek kwartalny: Zmiany w świecie podatków w pierwszym kwartale 2016 r., Finanse i prawo finansowe, vol. III, nr 1, marzec, s. 160-161. 